\title{
ASSESSMENT OF DAMAGES FOR PERMANENT INCAPACITATING INJURIES*
}

\author{
DONNA LEA HAWLEY**
}

\begin{abstract}
Within the last year personal injury awards in Canada have been assessed for amounts far exceeding those in the past. This paper examines the basis on which personal injury awards have been and are assessed. The treatment of this topic is delimited by restricting the discussion to only those awards made for serious per. sonal injuries-those that permanently incapacitate the plaintiff to a major extent. While once global awards were assessed to provide compensation for the total loss of the plaintiff, there now appears to be a trend towards assessment of damages for the actual loss of the plaintiff. Usually, the two most important heads of damage are loss of future earnings and cost of future care. Of these two it is the cost of future care which has been the primary cause of the dramatic increase in damage awards. Non-pecuniary damages are now usually given somewhat minor consideration in the awards. Other considerations on assessment examined in. clude income tax, considerations on appeal and the use of juries.
\end{abstract}

\section{INTRODUCTION}

The development of the law of damages for personal injury claims has been precipitated, to a large extent, by the developments of modern highway travel. 1 The victims of motor vehicle and other accidents may be compensated for their loss by the law of torts which allows the recovery of both special and general damages. Special damages, which generally include out of pocket expenses incurred by the plaintiff up to the time of the trial and which may encompass such items as medical, travel or funeral expenses, among other things, are specific to each case. Since special damages are pleaded separately from general damages and are itemized calculations of actual losses incurred by each particular plaintiff, it is difficult to include a consideration of their assessment in a discussion of assessment of damages. This study, therefore, will examine general damages only.

The assessment of damages usually follows a finding of liability on the part of the defendant. This discussion will assume that the defendant has been found to be liable for the plaintiff's injuries. Likewise, it will be assumed that contributory negligence by the plaintiff is not in issue, although the effect of a finding of contributory negligence does not reduce the calculated award which would compensate the injury incurred, but only reduces the amount of the judgment to the plaintiff by the determined degree, or percentage, of liability of the plaintiff.

An extensive range of injuries, including damage to reputations, nervous shock, multiple physical injuries and death, creates a cause of action for damages. The calculation of damages for each case varies with the type and extent of the injury, among other things. A great many considerations can and must be taken into account when assessing damages. Which of these considerations are applied depends, in part, upon the type of injury, its duration, and its effect on the life of the plaintiff. To facilitate discussion of the principles of assessment of damage for personal injury, only one type of injury will be considered - those which permanently incapacitate the plaintiff.

- The author wishes to extend her thanks to former Dean G. H. L. Fridman, Faculty of Law, University of Alberta, under whose guidance and direction this study was undertaken. Thanks are also extended to Ellen Jacobs, former Associate Dean, Faculty of Law, University of Alberta, for her advice; and to Ron G. Cummings, member of the Alberta Bar, who provided unreported decisions and many hours of valuable discussions.

* B.A., B.P.E., M.A., of the graduating class of 1976, Faculty of Law, University of Alberta.

' See Benham v. Gambling [1941] A.C. 157; Loney v. Voll [1974] 3 W.W.R. 193. 


\section{A. CATEGORIES OF INJURIES}

Willis $\mathrm{J}$., in considering the assessment of damage for a plaintiff who suffered a serious brain injury, said, ". . . it seems to me an almost impossible task to try and compare one appalling physical tragedy with another form of physical and mental tragedy. . .."2 Difficult though this task may be, it is important that such comparisons be made so that fair and reasonable awards can be determined. Personal injuries, because they cover a wide range of "hurts" to the body, can be classified, for the purpose of discussion, into two sets of opposing categories-permanent and temporary, and, incapacitating and non-incapacitating. These general categories produce four sub-categories of injuries: temporary non-incapacitating; temporary incapacitating; permanent non-incapacitating; and permanent incapacitating. ${ }^{3}$

\section{Temporary non-incapacitating}

Temporary non-incapacitating injuries are those which affect the plaintiff for a limited time and in a manner that does not greatly interfere with his normal life style. Such injuries include broken teeth, ${ }^{4}$ a broken nose, ${ }^{5}$ a broken jaw, ${ }^{6}$ and a concussion and minor fractures. ${ }^{7}$

\section{Temporary incapacitating}

Temporary incapacitating injuries are those which affect the plaintiff for a limited time, but in the manner which interferes with his normal life style by causing him to remain hospitalized, rendering him immobile, or prohibiting him from carrying on his work or hobbies. Examples of such injuries are an injured knee, ${ }^{8}$ and a broken hip. ${ }^{9}$

\section{Permanent non-incapacitating}

Permanent non-incapacitating injuries are those which affect the plaintiff for the duration of his life, but which do not necessarily interfere with his life expectancy or his ability to act in his normal, or near normal, life style. These include injuries that are referred to as permanent partial disabilities, and include such damage as the loss of one eye, ${ }^{10}$ the loss of one hand, ${ }^{11}$ disfigurement, ${ }^{12}$ burn scars on both legs, ${ }^{13}$ the loss of both legs, ${ }^{14}$ and the loss of both arms. ${ }^{15}$

\section{Permanent incapacitating}

Permanent incapacitating injuries affect the plaintiff for the duration of his lifetime in a manner which alters his former life style almost completely.

\footnotetext{
2 Cutts v. Chumley [1967] I W.L.R. 742 (Q.B.), at 748. here.

- Kwanie v. Penthouse Towers Led. [1972] 3 W.W.R. 266.

5 Hurshman v. Sobeys Stores 3 N.S.R. (2d) 323.

- Cachay v. Nemeth 28 D.L.R. (3d) 603 (Sask. Q.B.).

7 Muma v. Moore (1974) 1 O.R. (2d) 346, Can. Insurance Law Reporter 90.972.

- Rigby v. Corporation of City of Victoria [1973] 3 W.W.R. 128 (B.C.S.C.).

- Callow v. B.C. Distillers [1972] 4 W.W.R. 614.

10 Pelkey v. McCluskey 3 N.B.R. (2d) 708 (C.A.).

"Villeneuve v. Sisters of St. Joseph Hospital [1971] 2 O.R. 593.

12 Jesmer v. Bert Katz Real Estate [1973] 2 O.R. 346.

13 Pollock v. Lipkowitz (1971) 17 D.L.R. (3d) 766 (Man. Q.B.).

1" Badger v. Surkan [1973] 1 W.W.R. 302.

is Muhl v. David Lord Led. [1972] C.A. 537 (Que.).
}

3 Carter, Assessment of Damages for Personal Injuries or Death in the Courts of the Common-law Provinces 32 Can. Bar. Rev, 713, at 719, has classified damages into three categories: (1) the "total wreck", a complete incapacity to work and no enjoyment of life as a result of severe paralysis or brain injury or multiple injuries which completely cripple; (2) the "partial wreck", although the whole person is affected, there is still a limited ability to work and enjoy life; and (3) miscellaneous, loss of limbs, eyes and various forms of minor injuries are involved 
This type of injury includes such loss as birth deformities caused by Thalidomide, ${ }^{16}$ paraplegia, ${ }^{17}$ quadriplegia, ${ }^{18}$ and serious brain damage. ${ }^{19}$

\section{B. CATEGORIES OF INJURIES: EFFECT ON THE PLAINTIFF AND ON THE COURT}

The first three categories of injuries, temporary non-incapacitating, temporary incapacitating and permanent non-incapacitating, differ from the last category, permanent incapacitating, inasmuch as they affect the plaintiff for a shorter period of time, affect him in a less serious manner, or both. Generally, permanent incapacitating injuries can be considered separate from the other categories for the following reasons:

Firstly, the extent of damage inflicted on the plaintiff is the greatest. It involves a total loss of important body function to the plaintiff, forever. The plaintiff in Bisson v. District of Powell River ${ }^{20}$ received an injury in this category-quadriplegia, and was described by Bull J.21

The respondent's fifth and sixth cervical vertebrae in the neck were fractured in the accident, with the result that he is, and will continue to be to the end of his days, almost a com. plete quadriplegic. He cannot move his legs, and has no sensation in his body below his shoulders and neck, or in his arms except for an area on the outside of the shoulder extremity about halfway to the elbow. He can move his head and shoulders and can move his arms away from his body. He can bend his elbow upwards and has a very slight movement in his wrists. He cannot control his hands or fingers. His bladder and bowels are controlled artificially. He cannot perspire properly and has lost all sexual potency. No medical improvement in his condition is foreseen.

Injuries in this category generally are not curable as are some permanent partial disabilities, such as the loss of an arm or leg, which can be "cured" by replacing the lost natural extremity with a prosthesis.

Secondly, the change in the plaintiff's life style is the greatest. Because of the great extent of injury, the plaintiff is generally precluded from performing future activities such as engaging in physical work, ${ }^{22}$ caring for his own personal needs, ${ }^{23}$ and communicating properly with other people, ${ }^{24}$ and in addition to this, the injured person often has only a "mere existence"25 to look forward to.

These two features, the permanent loss of the use of the plaintiff's body or mind, coupled with the loss of the ability to live or enjoy life in a natural way, which so seriously and totally affect the plaintiff's life, create a need for a somewhat different approach to the assessment of damages. This difference does not affect the principles which govern damage assessments, but only the extent to which they are applied. Lord Devlin, in $H$. West \& Son v. Shephard, ${ }^{26}$ in discussing this issue, said: ${ }^{27}$

There is here an almost total loss of use of all the facilities or limbs, but compensation under this head must be assessed in the same way as it would be for a partial loss of a single limb or faculty. The degree is different but not the principle.

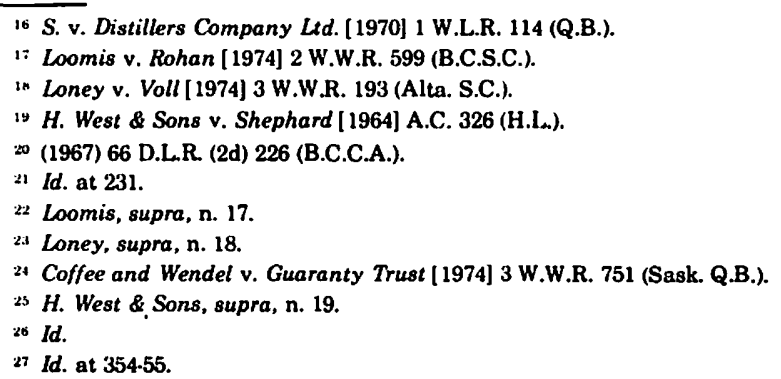




\section{GENERAL PRINCIPLES OF THE ASSESSMENT OF DAMAGES}

\section{A. GENERAL PRINCIPLES}

The quantum of damages is probably the most important aspect of civil action as far as the parties are concerned. The amount of money received, or paid out, is the factor which affects the parties directly and in a real manner. It is important that the courts make fair and adequate assessments of damages for personal injuries in order that the plaintiff may be justly compensated and the defendant not be unduly treated.

In their attempts to arrive at a method by which general damages can be assessed, the courts have developed a number of general principles. These are principles and not rules. "From the very nature of serious personal injuries the fact that they are personal injuries makes it inevitable that there are no precise rules for assessing damages." 28 This is evidenced by the variety of reasoning for the method of calculating damages given in the cases.

\section{Compensation}

The predominant reason for awarding damages is to compensate the victim for his loss and to ". . . award the injured party such a sum of money as will put him in the same position as he would have been if he had not sustained the injuries. . . ."29 Where the loss suffered by the plaintiff is a pecuniary one, the application of this principle is not a difficult task. Difficulties arise, though, when the loss suffered has no usual dollar value, as in cases of personal injury. The great variety of physical loss possible, even among the restricted class of permanent incapacitating injuries, compounded by the far reaching effects on the life and future of the victim, make the calculation of damages a Herculean task.

\section{Once-for-all award}

The plaintiff must sue in one action for all of the loss he has suffered, past, present and future. It is not possible to sue on separate occasions for separate heads of damage. Likewise, if more than one defendant is involved, all must be sued in the same action. The court, when assessing the damage award which will compensate the plaintiff, must award a lump sum, or a once-for-all award ${ }^{30}$ Different methods can be used to determine this total sum, but it is awarded only once, and for all the damage suffered.

\section{Award not to be Perfect}

Usually it has been held that damages cannot be perfect, ${ }^{31}$ but are reasonable compensation only. ${ }^{32}$ This is shown by the recent decision in Teno v. Arnold, ${ }^{33}$ in which the Supreme Court of Ontario, when assessing damages for a young girl who received severe brain damage when a car struck her as she crossed the road in front of her home, decided that it “... must arrive at a composite figure which, without attempting to allocate precise figures, represents what may be considered to be fair, not perfect compensation." ${ }^{34}$ This concept of fair compensation was delimited by Mr. Justice Kirby in Andrews v. Grand \& Toy, where he said:35

\footnotetext{
29 Loney, supra, n. 18 at 200.

29 British Transport Commission v. Gourley [1955] 3 All E.R. 796 (H.L.), at 799.

3o Oliver v. Ashman [1961] 3 All E.R. 323 (C.A.), at 333.

31 Coffee, supra, n. 24, at 758.

$32 \mathrm{H}$. West \& Sons, supra, n. 19 , at 346.

33 Unreported decision of the Ontario Supreme Court, September 27, 1974, per Keith J.

34 Id. at 79.

3s Unreported decision of the Alberta Supreme Court, Calgary, July 31, 1974, per Kirby J., at 7.
} 
[There are] two principles applicable in the assessment of damages for serious injuries, such as quadriplegia:

(1) The plaintiff is entitled to full compensation for pecuniary loss past and future, subject with respect to loss of prospective earnings, to allowance for the contingencies of life and to discount for accelerated payment.

(2) With respect to non-pecuniary loss, such as pain and suffering, shortened expectation of life, loss of amenities, which do not lend themselves to mathematical calculation, damage should be fair and reasonable.

It appears from this decision that damages should be fair, meaning without a strict mathematical formula by which to calculate their value, only for non-pecuniary losses. Loss of future earnings, with some allowances, has now received what is approaching a consideration for perfect compensation.

\section{Actual use of award by plaintiff not considered}

The actual use to which the plaintiff will put the money awarded has been held to be of no concern to the court. Lord Justice Holroyd Pearce, in Oliver v. Ashman, ${ }^{36}$ considered that the ability of the plaintiff to use his award was irrelevant to their assessment. He further stated: "There is no condition that [the plaintiff] should spend or use the damages. They are his to save or to spend or to dissipate in any useful or useless manner that he may choose."37 It was likewise stated by Lord Morris of Borth-y-Gest, in $H$. West \& Sons v. Shephard:38 "If damages are awarded to a plaintiff on a correct basis, it seems to me that it can be of no concern to the court to consider any question as to the use that will thereafter be made of the money awarded." In this case the House of Lords was considering the award made to a 41 year-old woman who sustained severe brain damage in a motor vehicle accident. The question concerning the court was: when assessing damages does it matter that the plaintiff will not be able to spend or enjoy the money him. self? Lord Pearce expressed the view that this was not to be considered by the court. He said: 39

The court has to perform the difficult and artificial task of converting into monetary damages the physical injury and deprivation and pain and to give judgment for what it considers to be a reasonable sum. It does not look beyond the judgment to the spending of the damages. If it did so, many difficult problems would arise. Similar sums awarded for similar suffering may produce wholly different results. To a poor man who is thereby enabled to achieve some cherished object such as the education of his family the sum awarded may prove to be a more than adequate consolation. To a man who already has more money than he wants, it may be no consolation at all. But these are matters with which the court is not concerned. Whether the sum awarded is spent or how it is spentis entirely a matter for the plaintiff or the plaintiff's legal representatives.

This principle appears not to apply in Alberta, where Mr. Justice Manning, in Loney v. Voll,40 directed that the damages payable to the plaintiff, an eighteen-year-old woman who was rendered a quadriplegic in a motor vehicle accident, be handled by trustees on her behalf. The court felt a concern for the plaintiff's welfare, which was encouraged by the anxiety of a social worker who felt that some person might take advantage of the plaintiff, and persuade her". . . to spend her money in such a way that it may be lost to her." 41 This point was considered well taken, and Manning J. expressed his view: ${ }^{42}$

\footnotetext{
${ }_{36}$ Oliver, supra, n. 30.

37 Id. at 328.

3o Supra, n. 19, at 349.

30 Id. at 364 .

to Supra, n. 18

1I Id. at 221.

12 Id.
} 
I think the money should be handled by trustees and that [the plaintiff] should, in her own interests, have available for spending pursuant to her own volition, only relatively small sums from time to time. I think the Court has inherent jurisdiction over its awards of damages to the extent that it is entitled to direct payment of damages to a trustee in a case of this nature.

Regardless of whether or not the plaintiff will actually spend the award or not, the use for which the money should be spent is of importance in determining the amount of damages. Damages are often awarded to ensure the plaintiff adequate security; ${ }^{43}$ to allow the plaintiff to purchase special equipment, special facilities and special personal care; 4 to provide for maintenance and future income; ${ }^{45}$ to make good a financial loss; ${ }^{46}$ and to compensate for a future existence changed by the injury, including loss of expectation of life, loss of amenities of life, and for pain and suffering. ${ }^{47}$ The damages awarded to the plaintiff should: 48

... be sufficient to ensure that he will be properly looked after by others in any situation which can reasonably be foreseen, so that even rather improbable contingencies will be covered.

But it is generally considered that it is the plaintiff's, not the court's responsibility to see that this end is achieved.

\section{B. HEADS OF DAMAGES}

Heads of damage are used to differentiate the various aspects of loss which arise from an injury into components for which a value, in terms of a monetary sum, can be assessed. From these separate considerations a total, or global, sum is derived. Ogus ${ }^{49}$ describes these components under three major headings as: (i) Positive losses, or the diminution of existing assets by expenses incurred; (ii) Consequential losses, or the loss of future profits and earnings; and, (iii) Non-pecuniary losses, or the loss of assets which haveno monetary value. The more prevalent terminology applied to these heads is that used by Kemp: $:^{50}$ (i) Special damages, the actual loss or expense incurred by the plaintiff which arose because of the action of the defendant, to the time of trial; (ii) Pecuniary loss, or those future losses which the plaintiff will suffer, by reason of the act of the defendant, which can be calculated in terms of money; and, (iii) Non-pecuniary lossès, or those future losses which the plaintiff will suffer, by reason of the act of the defendant, which are impossible to assess by arithmetical calculations.

The heads of damage utilized by Ogus are not the normal terminology of the courts. The headings used by Kemp are more commonly used, but in a slightly different manner. Damages are of two specific types-special and general. Special damages, as Kemp describes them, are those actually incurred by the plaintiff up to the trial. General damages, on the other hand, are for all those losses incurred after trial, and include both pecuniary and non-pecuniary damages.

\section{Pecuniary Damages}

\section{Pecuniary damages are those that compensate for future losses which}

43 Oliver, supra, n. 30.

14 Andrews, supra, n. 33 at 11.

is Loney, supra, n. 18.

$16 \mathrm{H}$. West \& Sons, supra, n. 19.

47 Id.

4s Oliver, supra, n. 30, at 340, per Pearson LJ.

19 Ogus, The Law of Damages 19 (1973).

so Kemp, Kemp and Havery, The Quantum of Damages, Volume I: Personal Injury Claims, 8 (3rd ed. 1967). 
are capable of exact arithmetical calculation. A recent Canadian case, Andrews v. Grand \& Toy, 51 held that the ". . . plaintiff is entitled to full compensation for pecuniary loss past and future...." Only future pecuniary loss is included in general damages, and it encompasses such items as loss of prospective earnings, ${ }^{52}$ handicap in the labour market, ${ }^{53}$ material loss other than loss of earnings, ${ }^{54}$ and cost of future care including special equipment, special facilities, and special personal care..$^{55}$

\section{(a) loss of prospective earnings}

This is usually one of the most important heads of damage in cases of permanent incapacitating injuries, since it can be a very substantial amount. The factors which are considered in order to determine the amount under this head include: 56
(a) The level of earnings on which the award is to be based.
(b) The expectation of life of the injured person.
(c) The expectation of his working life.
(d) Duplication of the cost of future maintenance.
(e) Whether allowance is to be made for income tax.
(f) Whether inflation trends are to be taken into account.
(g) Contingencies and "the hazards of life".
(h) The method to be used in determining the present value of anticipated earnings.

There are two major methods for calculating the future loss of earnings: (i) the multiplier, by which the lost net average income (the multiplicand) is multiplied by the number of lost working years (the multiplier); 57 and (ii) the actuarial technique, which provides a useful guide when ". . . the future rate of income loss is reasonably certain and . . . the plaintiff has sustained no substantial loss of life expectancy." 58 By this method the court can use tables which give values of future lost income based on the age, sex and income of the individual. These methods of calculation will be discussed in greater depth later in this paper.

\section{(b) handicap in the labour market}

This head of damage is similar to loss of prospective earnings, the difference between them being one of degree. Whereas the former head contemplates a total loss of all future earning power, this head compensates for a reduction in the plaintiff's earning power. Generally, this head affects persons who suffer a permanent non-incapacitating injury, such as the loss of an arm, hand, or leg, which results in the plaintiff being required to seek employment in a job different from the one he held before the accident, for example, a manual worker who must give up a high paying construction job for a lesser paying clerical job. The difference in the prospective earnings between the two jobs may be calculated and awarded under this head.

Permanent incapacitating injuries generally preclude the plaintiff from any hope of obtaining gainful employment in the future, resulting in this head being of little use in the calculation of damages. Most often the type of activities that can be carried on by a quadriplegic, such as typing, can be

\footnotetext{
ss Supra, n. 35, at 7.

s2 Id.

ss Kemp, supra, n. 50, at 9.

st Id. at 10.

ss Andrews, supra, n. 35, at 11 .

$\rightarrow$ Id. at 13.

57 Ogus, supra, n. 49, at 188.

ss Id. at 190.
} 
considered little more than pastimes, while those who are suffering from brain damage often cannot engage in even this small amount of activity. Paraplegics, on the other hand, may be the only persons in this category of injuries who may be able to claim under this head. In Loomis v. Rohan, ${ }^{59}$ Aikins J. discussed the problem of a 44 -year-old paraplegic: ${ }^{60}$

Clearly he can never return to his trade[as an ironworker], and indeed, he will never be able to do any physical work except possibly certain types of manual bench work.

He said further.

The work available to paraplegics is very limited. Some paraplegics are engaged at clerical work, manual work at a bench, such as repair work or assembly work, shoe repairing, and dispatching for a taxi company or a trucking firm.

The court found that the plaintiff in this case, because of his injury, his age and his lack of education, probably would not be able to support himself in the future. If the plaintiff were able to earn money, he would be entitled only to the difference between the amount he will actually earn, and the amount he would have earned before the injury. In this case, Aikins J. had to consider the amount to discount from the award by reason of the plaintiff's probable future earnings. He held: "In the overall award I discount by a very modest fact only for the possibility that the plaintiff may be able to get and keep some remunerative employment." 61

It appears, therefore, that this head of damage has little application for plaintiffs who suffer from a permanent incapacitating injury, with the possible exception of paraplegics who have the capacity to be trained for a new type of employment.

\section{(c) material loss other than loss of earnings}

Material benefits that accrue from the plaintiff's employment, such as free board and lodging, accumulative sick leave, and the opportunity of making or enhancing a reputation, which have been lost due to the plaintiff's injuries, have been compensated for under this head. ${ }^{62}$ The losses suffered under this head are peculiar to the circumstances of each case and arise only where they exist and can be proven as such.

\section{(d) cost of future care}

The cost of future care for a plaintiff who suffers a permanent incapacitating injury can be, and often is, the largest part of the damages, in terms of actual money awarded. ${ }^{63}$ Persons who suffer from injuries in this category generally must have special personal care for the remainder of their lives. An example of such needs is the description of the plaintiff in Loney v. Voll.64

[The plaintiff] is a quadriplegic as a result of the accident. She has no feeling below her chest and has no use of her fingers but fortunately some use of her arms.

[The doctor said] . . . "she needs constant attention" and that whoever attends her should be "someone of reasonable intelligence sufficient to be aware of the potential problems and understanding of the care she requires-skin, bladder, feeding, et cetera, sufficient strength to lift her and move her from place to place." . . . she is quite unable to move herself.

\footnotetext{
59 Supra, n. 17.

so Id. at 601 and 603 .

61 Id. at 604.

62 Kemp, supra, n. 50, at 10.

63 See Andrews, supra, n. 35; Loney, supra, n. 18.

64 Supra, n. 18, at 198, 224.
} 
... she would need "constant care 24 hours, because she needs to be turned at night and she has to have certain nursing needs which have to be taken care of in the evenings as well as during the day".

. . . She needs help for all "transfer activities", such as moving between her bed and her wheelchair and also in moving during the night. She is not able to wash herself . . . she needs "constant attention" . . . she needs two attendants.

The cost of this future care (which does not include normal living expenses) can include the hiring of necessary skilled assistants; 65 a home of his own; ${ }^{66}$ special equipment such as wheelchairs ${ }^{67}$ an electric typewriter, ${ }^{68}$ and hand controls for an automobile; ${ }^{69}$ future medicines, doctor and hospital expenses; ${ }^{70}$ and special equipment and alterations in the home, such as railings and ramps. ${ }^{71}$ The cost of each item can be estimated and a total yearly sum at which when multiplied by the number of years of the plaintiff's life expectancy will yield a sum that may be used to determine the award under this head. The court may otherwise look at the type of special expenses necessary and set an amount based partly on previous awards of a similar nature. This head of future expenses will be discussed in detail later.

\section{Non-pecuniary damages}

Non-pecuniary damages are those for which no mathematical calculations are possible since they are not derived from economic considerations. Such losses generally include such things as pain and suffering, loss of amenities of life, and loss of expectation of life, among others. As opposed to pecuniary losses which usually receive full compensation, nonpecuniary losses "... which do not lend themselves to mathematical calculation, damages should be fair and reasonable."72 The difficulties involved in assessing a dollar figure for these losses presents a major problem and will be considered in a later portion of this paper.

\section{(a) pain and suffering}

A person is entitled to be compensated for past, present and future pain and suffering that is actually experienced. If the plaintiff is unconscious and does not experience pain or suffering no award can be allowed under this head.73 Pain and suffering are different concepts which include actual physical pain suffered, and the mental suffering which may arise from the realization that one's life has been shortened, or that a serious disability is permanent. $^{74}$

\section{(b) loss of amenities of life}

"This head embraces everything which reduces the plaintiff"s enjoyment of life considered apart from any material or pecuniary loss which may be attendant upon the loss of amenity." 75 Lost amenities include losses such as the inability to carry on a normal life, the effects on the personality of the plaintiff created by disfigurement, and the loss of the pleasures of married

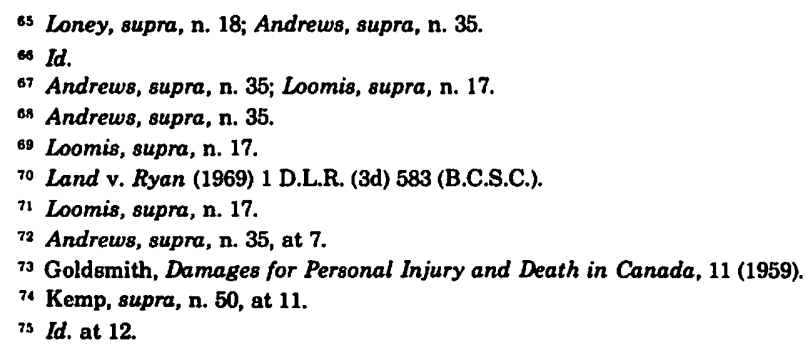


life. ${ }^{76}$ The object of this head is to compensate the plaintiff for the effect of the disability on his enjoyment of life. ${ }^{77}$

\section{(c) loss of expectation of life}

This head compensates the plaintiff for the years that will be denied to him as a result of the defendant's actions which caused him an injury that brings death at a time earlier than his normal life expectancy. Generally only a moderate sum is awarded under this head, and it is irrelevant whether or not the plaintiff is aware of his shortened life expectancy. ${ }^{78}$

\section{(d) other non-pecuniary losses}

Other losses that have been considered include: impairment or loss of anatomical structures or body tissue, such as disfigurement or the loss of an internal organ; ${ }^{79}$ loss or impairment of physiological functions; ${ }^{80}$ the effect of the injury on the health of the plaintiff; $; 1$ inconvenience and discomfort; 82 and, aesthetic prejudice or the change in physical appearance that affects a person whose physical appearance is important to him in his job. ${ }^{83}$

\section{APPLICATION OF THE GENERAL PRINCIPLES TO THE ASSESSMENT OF DAMAGES FOR PERMANENT INCAPACITATING INJURIES}

The actual method whereby an award, in terms of dollars, is achieved, for a plaintiff with a permanent incapacitating injury, has varied greatly. In dealing with a plaintiff who has suffered an injury which results in quadriplegia, paraplegia, multiple injuries or brain damage, the courts have been inconsistent in their decisions in respect to the factors on which they based their decision. A major factor which has been emphasized is the method of achieving the sum of the award. Two opposing views have emerged. The first considers that the award should be calculated as a lump sum, or single dollar figure, which represents the total amount allowed to compensate the victim; and the second arrives at the sum by totalling the amount due under separate heads of damage. If heads of damage are used to assist in the determination of the award, and they often are in some manner or other, which heads to use and what comparative value to place on each head have been further problems which the courts have had to resolve. Other considerations which the courts have had to weigh in their calculations include: the assessment of tax on the award; the influence of juries; the possible treatment of the award by a court of appeal; and whether an award should be given as a lump sum or by periodic payments. Each of these aspects of calculating an award will be examined separately.

\section{A. GLOBAL SUM VERSUS COMPONENT AWARD}

There are three methods whereby general damages are assessed. These are (i) by assessing a global figure which represents the total compensation to the plaintiff-the global method; (ii) by calculating or estimating an

\footnotetext{
30 Carter, Assessment of Damages for Personal Injuries or Death in the Courts of the Common-law Provinces 32 Can. Bar Rev. 713, at 725 .

7 Ogus, supra, n. 49, at 206.

7s Carter, supra, n. 76, at 726.

79 Street, Principles of the Law of Damages, 66 (1962).

so Id. at 64 .

is Carter, supra, n. 76, at 724

82 Kemp, supra, n. 50, at 12.

ss Guthrie, Principles of Assessment of Personal Injury Claims (1967) 27 R. du B. 157, at 177.
} 
amount under each of the heads of damage and to compute the total of these as the compensation due to the plaintiff - the component method; and (iii) by a combination of these two methods in which damages are calculated under the heads and their total is "checked" against a global sum-the cross-check method. There has been no apparent consistency in the use of these methods by the courts when assessing damages for permanent incapacitating injuries and the existence of these differences in calculation has been recognized by the courts. ${ }^{84}$

\section{The Global Method}

Generally, it appears that a majority of the cases have been disposed of by the assessment of a global sum. ${ }^{85} \mathrm{It}$ is possible that the choice of this method of assessment may arise from a subjective outlook by the courts involved. A subjective outlook is one which bases its assessment on the loss as a whole that is experienced by the plaintiff, and which has as its purpose the alleviation of the victim's plight. Such was the view expressed by Harman L.J. in the English case of Warren v. King, ${ }^{86}$ when he said:87

It seems to me that the first element in assessing such compensation is not to add up items such as loss of pleasures, of earnings, of marriage prospects, of children and so on, but to consider the matter from the other side, what can be done to alleviate the disaster to the victim, what will it cost to enable her to live as tolerably as may be in the circumstances? This will involve, first, an estimate of the infant plaintiff's expectation of life, and next an estimate of the cost of such help as she needs.

The general philosophy behind a global award based upon such a view is that the life of the plaintiff must be viewed as a totality and the award must compensate by making up for the suffering caused by the loss.

The global sum is not arrived at by use of mathematical calculations. It has been held that the award ". . . cannot be a comparatively precise computation ...."88 but the award must "... be imprecise and nonscientific." 89 This rejection of the use of mathematical calculation was expounded by Keith J. In Teno v. Arnold in this way: ${ }^{90}$

With respect to the latter assessment [in Andrews v. Grand \& Toy] I have deliberately refrained from carrying out a mathematical exercise of the kind that Kirby J. did becauseI do not think the figures he used in arriving at what was required monthly for the purposes indicated are susceptible of precise calculation even at present and must inevitably become inapplicable with the passage of time. If that is so, any result obtained by the use of such figures must be open to attack.

And further:

I cannot and therefore ought not to attempt to base my assessment on any mathematical calculation. Rather having regard to the evidence including the mathematical tools placed at my disposal, I must arrive at a composite figure which, without attempting to allocate precise figures, represents what may be considered to be fair, not perfect compensation.

Concurrent with the rejection of mathematical calculations is the rejection of the notion that a specific amount should be awarded for each of the heads of damage. This has been expressed as ". . . an award of general damages is not simply the total one may arrive at by adding up the par-

\footnotetext{
84 Eg., Andrews v. Grand \& Toy, supra, n. 35.

ss Oman v. Moroz [1973] 2 W.W.R. 577 (Alta. S.C.); Coffee v. Guaranty Trust, supra n. 24; Hill v. The Queen [1973] 2 O.R. 282 (C.A.); Cyr v. Charron (1971) 3 N.B.R. (2d) 290 (N.B.S.C.).

${ }_{86}^{8}$ [1963] 3 All E.R. 521 (C.A.).

87 Id. at 528 .

Land v. Ryan, supra, n. 70, at 591.

89 White and White v. Parkin and Camex Developments Ltd. et al. [1974] 3 W.W.R. 509 (B.C.S.C.) at 518.

0 Supra, n. 33, at 78-79.
} 
ticular amounts that may be assigned to each heading of damage." 91 The heads of damage are considered by the court to show the extent of the plaintiff's loss, rather than as a means to calculate compensation. This is supported by Lillico v. Glimps, ${ }^{92}$ a case in which the young woman plaintiff was rendered a quadriplegic by an automobile accident. In this case the court set out ten factors which were thought to be the most important to consider, including many normally referred to as the heads of damage. The court then made an award without mentioning the effect, if any, which the consideration of these ten factors had on the sum awarded. A similar decision had been reached the previous year in England by Hinchcliffe J. in $S$. v. Distillers Company Ltd.:93

I get the impression that the reformers would like an alteration in the law so that in assessing damages pecuniary loss would be itemized and based on actuarial calculations, That time has not yet arrived. In both these cases [herein] the court when assessing the general damages will have regard to the cost of special care, to the loss of earning capacity and the deprivation or loss of amenities suffered by each infant plaintiff. But of course these are not separate heads of compensation. The court will regard them separately because it will assist the court to reach a global sum which is just and reasonable.

In both of these cases the court recognized that there were many aspects to, or reasons for a personal injury award, but decided that it was impossible or impractical to assess a value under each, preferring to assess a global sum.

\section{The Component Method}

The second method used to arrive at an award for personal injury damages is to calculate the loss incurred under the heads of damage. This method appears to stem from an overriding objective philosophy, or one which deals with actual facts and is uncoloured by feeling or opinion. Damages based on an objective scale are awarded for actual loss of an objective good or tangible asset, and not for a sense of loss or the psychological effect on the plaintiff.

Which heads of damage are used depends on the facts of each case, since an award can be made only for the losses actually suffered. Little use can be made of the awards calculated in other cases, and ". . . the consideration of awards given to quadriplegics or paraplegics in other cases [is not] helpful because of the diversity of the extent of injuries and circumstances in the various cases." 94

In two English cases in which the plaintiff suffered serious brain damage, heads of damage were employed. In the first the heads used were: (i) loss of future earnings, (ii) loss of expectation of life, and (iii) general loss ${ }^{95}$ In the other case, in which the plaintiff had severe intellectual loss, the court held:96

There is no dispute that the heads under which I should consider, as I do, the assessment of damages are: (a) pain and suffering; (b) loss of the amenities of life; (c) cost of caring for her for the rest of her life in a private institution; (d) loss of probable future earnings; and (e) loss of expectation of life. I am satisfied that [the plaintiff] is entitled to an award under each of these heads. ...

Two Canadian cases, which involved young men who were rendered quadriplegics, grouped the non-pecuniary heads together when assessing

\footnotetext{
9) Loomis v. Rohan, supra, n. 17, at 607.

92 [1971] 1 W.W.R. 750 (Alta. S.C.).

93 Supra, n. 16, at 125.

94 Bisson v. District of Powell River, supra, n. 20, at 229.

os $H$. West and Sons v. Shephard, supra, n. 19.

of Cutts v. Chumley, supra, n. 2, at 748.
} 
damages. In the first, Bisson v. District of Powell River, Bull J.A. held:97

\begin{abstract}
As to the non-pecuniary heads, I would feel secure in saying that the loss attributed to life expectancy .... and "pain and suffering" would be in this case of a more or less nominal amount and the main damages would be awarded with respect to the grievous injuries themselves together with the consequent loss of amenities, including mental suffering, consequent thereto. I think that $\$ 50,000$ may be considered a reasonable amount to cover these heads . . . the sum of $\$ 236,000$ is left to cover the two heads for loss of future earnings and cost of future maintenance and expenses.
\end{abstract}

In the second case, Andrews v. Grand \& Toy, Kirby J. further merged the non-pecuniary heads: 98

I propose therefore to consider and assess damages separately under the following headings:

1. Special damages including hospitalization and loss of wages to date of judgment;

2. Prospective loss of earnings;

3. Compensation for physical and mental pain and suffering endured and to be endured, loss of amenities and enjoyment of life, loss of expectation of life.

4. Cost of future care including special equipment, special facilities, and special personal care.

An amount was assessed under each of these heads and a total amount calculated by the addition of these four figures.

The use of heads of damage to calculate an award has been considered by courts of appeal. The House of Lords did not dispute this method of calculating the award in West v. Shephard. ${ }^{99}$ Two years later, in 1966, the Supreme Court of Canada considered an appeal of quantum in The Queen $\mathbf{v}$. Jennings, ${ }^{100}$ based on a total of the amounts determined for various heads of damage. The trial judge had stated ". . . that while it was not customary to assess damages item by item he found it desirable to do so in this case."101 The Supreme Court did not question the desirability, or the frequency, of the use of heads of damage. Without stating its method as such, the Supreme Court discussed the quantum under the component parts by which it was assessed in much the same manner as the trial and appeal courts did, and concluded that the award was not excessive. The British Columbia Court of Appeal likewise did not dispute the use of heads of damage in Bisson $\mathbf{v}$. District of Powell River but used the heads to reduce the award. Bull J.A. reduced the award for the following reason:102

I am of the opinion that the excessive feature in the award stems essentially from the apparent error in the capitalizing process used in ascertaining compensation for the prospective costs of maintenance and the loss of future earnings . . . pure arithmetic does not always lead to a just result where there are many imponderables, I am of the view that in this case such excess is reasonably capable of ascertainment on a mathematical basis. . . .

The Manitoba Court of Appeal found the total award in Sabel v. Williamson, ${ }^{103}$ which was calculated using two heads of damage, excessive, and reduced the award without reference to either head considered by the trial court.

\title{
3. Cross-check system
}

The cross-check system of assessing damages is not recognized as a method by Canadian courts, but it appears to some extent in many of the

\footnotetext{
97 Supra, n. 20, at 241.

98 Supra, n. 35, at 711.

99 Supra, n. 19.

${ }^{100}$ [1966] S.C.R. 532.

301 Id. at 540 .

102 Supra, n. 97, at 243.

103 (1967) 61 D.L.R. (2d) 234 (Man. C.A.).
} 
decisions. It encompasses a merging of the subjective and objective views towards the assessment of damages. Generally an award is made objectively and checked subjectively. This occurs when an award is arrived at through some mathematical means, regardless of the degree of calculation, and then the total award is looked at (i) in terms of the cost of purchasing an annuity which would provide for the remainder of the plaintiff's life, (ii) in terms of the award being excessive, or (iii) in relation to awards for similar injuries or loss as evidenced by other cases.

The objective and subjective style of assessing damages are also merged in a second manner. It is not a cross-check system, but rather a division of damages into those which can be calculated objectively and those which are better assessed subjectively. This scheme was employed in the recent case of Andrews v. Grand \& Toy, where Kirby J. set out these two ideas:104

(1) The plaintiff is entitled to full compensation for pecuniary loss past and future, subject, with respect to loss of prospective earnings, to allowances for the contingencies of life and to discount for accelerated payment.

(2) With respect to non-pecuniary loss, such as pain and suffering, shortened expectancy of life, loss of amenities, which do not lend themselves to mathematical calculation, damages should be fair and reasonable.

This method acknowledges the unrealistic nature of attempting to assess damages for permanent incapacitating injuries by one method alone. It allows for mathematical calculation of assets actually lost and speculative assessment of the losses felt by the plaintiff, with the intention that when they are combined a fair compensation will result.

\section{(a) cross-check by the cost of an annuity}

When determining the amount of cost of future care or the award to compensate for the loss of future earnings some courts have compared their awards to, or based them on, the cost of an annuity which would provide for a periodic payment equal to the loss. In these cases the court is seeking a lump sum figure which, if invested at a given interest rate, would provide monthly or yearly returns for the life expectancy of the plaintiff. The cost of such an annuity has been used as a method to determine part of the award, ${ }^{105}$ or as a "convenient and useful check." 106

\section{(b) cross-check as being excessive}

A global award that was considered not to be "exorbitant" by the trial judge who assessed it was allowed for a quadriplegic plaintiff. ${ }^{107} \mathrm{On}$ appeal, if the amount awarded is not excessive it will not be disturbed. ${ }^{108}$ "Damages cannot be treated as excessive merely because they are large, . . ."109 but if there has been some error in the calculation of the compensation for loss of future earnings and the cost of future care this can be considered to be excessive, ${ }^{110}$ and the award will be accordingly reduced.

\section{(c) cross-check by awards from other cases}

The quantum of damages assessed is sometimes checked by comparing it with the amount assessed in cases of similar loss. This can be applied to the amount assessed for a single head of damage, such as for the loss of expecta-

\footnotetext{
104 Supra, n. 35, at 6.

105 Loomis v. Rohan, supra, n. 17, at 602

100 Teno v. Arnold, supra, n. 33, at 70.

${ }^{107}$ Cyr v. Charron, supra, n. 85, at 291.

108 Jennings v. The Queen, supra, n. 100, at 543.

109 Bisson v. District of Powell River, supra, n. 20, at 240.

$110 \mathrm{ld}$. at 243.
} 
tion of life, ${ }^{111}$ or for damages as a whole. ${ }^{112}$ An award may be found by a court of appeal to be inordinately high if the plaintiff's injuries are found to be not as serious as those in other cases of similar awards. ${ }^{113}$ Likewise, a trial court may feel bound by awards for similar injuries in other cases, but adjust the award for any differences in physical impairment or ability that exists. ${ }^{114}$

The cross-check method appears to produce a calculated yet fair award. It allows precise computation of those aspects of damages which by their nature are capable of mathematical assessment, such as the probable cost of future care and lost future earnings. This type of assessment permits the court to make allowance for special circumstances in each case and for differences in the plaintiffs' capacity which result from similar injuries. The subjective checking of the award in terms of excessiveness and the cost of an annuity or in comparison to similar cases, would tend to keep the element of "fairness" in the award and result in an amount of consistency and certainty in awards.

There appears to be an element of uncertainty in how the courts will assess a personal injury award. Although lump sum awards have been common, especially, it seems, in English cases, more recent Canadian cases are taking into account the various aspects of the award and are calculating specific amounts under the heads of damage. It may be that lump sum awards lend more certainty to the law of damages since like injuries could receive like compensation, while awards calculated by the heads of damages give a "fairer" award to the particular plaintiff by attempting to compensate for his exact loss, which may be different from that of another person who has a similar unjury. Each method has its merits and faults and will probably be used until the appearance of a form of fixed-value compensatory scheme.

\section{B. THE HEADS OF DAMAGE CONSIDERED FOR PERMANENT INCAPACITATING INJURIES}

\section{Pecuniary Heads}

Pecuniary heads of damage are those which produce the substance of, or the greatest part of an award for permanent incapacitating injuries. These usually consist of the two major heads-loss of future income, and cost of future care. These two heads are capable of mathematical calculation and the calculations vary with the type of employment, age, sex and life expectancy of the plaintiff, and with the family help available, type of accommodation expected, personal assistance and equipment required for the future. These considerations assure that each award is specifically created for the particular plaintiff.

\section{(a) loss of future income}

The purpose of an award under this head was succinctly phrased by Kirby J.:115

The sole function of an award for future maintenance or loss of future earnings is to provide a lump sum which represents the present value of those future payments, payable monthly or annually, as the case may be. It should not be concerned with building up an estate for the plaintiff.

111 H. West \& Sons v. Shephard, supra, n. 19, at 348.

112 Loney v. Voll, supra, n. 18, at 226.

113 Sabel v. Williamson, supra, n. 103, at 245.

i11 Oman v. Public Trustee, supra, n. 85, at 580-81.

is Andrews v. Grand \& Toy, supra, n. 35, at 23. 
The award for loss of future income is intended to provide an amount equal to the wages the plaintiff will no longer receive. It is irrelevant to this end whether the court arrives at the amount by subjectively considering the plaintiff's lost earning capacity or by objectively calculating his lost prospective earnings.

Mr. Justice Kirby, in Andrews v. Grand \& Toy, has described two alternative methods of capitalizing an amount for prospective earnings. The first was to determine what sum of money would have to be invested today to produce the required monthly income, without encroaching on the capital; the second was to determine what sum of money was required to produce the desired monthly income and extinguish itself at the end of the stipulated period. The second method was adopted in Andrews because it compensated for the lost wages but did not over-compensate by the build-up of an estate. This method was also employed in Loomis v. Rohan, ${ }^{116}$ where the capital sum required was calculated so that all capital and income would be consumed at the end of the given period. Actuaries often give evidence which provides the court with an amount that would have to be invested, at a fixed interest rate, to provide the plaintiff with an annual amount equal to the amount he would have earned.117

In England the award for loss of future earnings is calculated only for the years remaining in the plaintiff's life expectancy. Willmer L.J. explained this in Oliver v. Ashman: "The prospective earnings which a person might have earned during a period when ex hypothesi he will already be dead strike me as far too speculative to be capable of assessment by any court of law."118 Thus, in England, if a 20-year-old plaintiff has a life expectancy of 5 years, he can claim damages for loss of future earnings for 5 years only, and not for 45 years of age 65 . Salmond describes it this way: ${ }^{19}$

The English rule leads to the anomaly that the dependants of an incapacitated plaintiff who dies within three years of the accident, having obtained judgment against the defendant, are much worse off than if he had been killed at once, for in that case they could have recovered under the Fatal Accidents Act damages based upon the basis of the deceased's survival for the full period of his pre-accident expectancy.

This principle probably does not apply in Canada, as the following cases show. Cartwright J., in The Queen v. Jennings, when considering this point said in an obiter comment: 120

Before parting with the matter I wish to make it clear that I am not expressing agreement with the view, apparently entertained by both the learned trial judge and the Court of Appeal, that because the normal life expectancy of the plaintiff of 22.43 years has been reduced by his injuries to 5 years he should be compensated only for the earnings he would have been expected to receive during the 5 year period.

The British Columbia Court of Appeal failed to make a decision on this in Bisson v. District of Powell River, where McFarlane J.A. considered the issue: ${ }^{121}$

... I have not given consideration to the question of whether the capitalizing process with respect to loss of future earnings should be based on the expected working life span prior to the accident of 33 years (as was done in this case) or on the shortened life expectancy of 28 years. In the English view the earnings in the "lost years" should not be included. . . . Ap-

\footnotetext{
its Supra, n. 17, at 602 .

11: Eg., While v. Parkin, supra, n. 89, at 517; Andrews v. Grand \& Toy, supra, n. 35, at 23.

118 Supra, n. 30 , at 338.

119 Salmond on the Law of Torts (16th ed. 1973), at 587.88.

izo Supra, n. 108, at 543.

221 Supra, n. 20, at 245.
} 
parently the situation is not so clear in Canada, . . . The point was not raised in this appeal, and I let it lie fallow.

Although the Court of Appeal made no statement in support of the principle of assessing damages for lost earnings on the normal life expectancy of the plaintiff, the fact remains that it did not choose to reject it. This question was discussed in detail in Andrews v. Grand \& Toy. After a review of the major cases and an examination of the major texts on damages, Kirby J. came to the conclusion that a plaintiff is entitled to damages for ". . . loss of future earning capacity on his expected working life span prior to the accident,"122 minus what he would otherwise have spent on his maintenance during that period when he will no longer be alive. According to this decision a plaintiff will be compensated for loss of future income for the years from the time of the accident to the time of his normal retirement age, a departure from the English practice.

The award for lost future earnings is a rather simple calculation when the wages of the plaintiff and the number of expected working years are known. An amount can be computed which, when invested at a known interest rate, will supply the required monthly amount for the time indicated. It is much more difficult to make an award under this heading when the probable future wages of the plaintiff are unknown. In two cases in which the plaintiff was a young quadriplegic woman this problem in assessment arose. In one, Oman v. Public Trustee, Bowen J. said:123

... if she had lived a normal life, there was a possibility of her achieving a university education and a commensurate income which would go with it, and that now, while it is possible that such can be achieved, it becomes very improbable and therefore a loss of earnings is also to be taken into account in assessing a general award. . . .

The court did not attempt to calculate an amount for loss of future earnings, but awarded a lump sum as general damages. The other case was Loney v. Voll, ${ }^{124}$ in which no mention was made of the plaintiff's loss of future earnings; rather an award was made to provide for adequate future care, an item which is normally an expenditure of income.

The amount reached in calculations of the future income must be reduced for contingencies of life. The contingencies have been described in this way: ${ }^{125}$

... even if he had not been injured in this accident, [he] might still have been disabled by some other cause, he might have become ill, he might have been laid off-any number of things might have occurred that would have diminished his earning capacity, foreshortened his life, or reduced his pension.

The amount for contingencies must be deducted from the capital sum required to invest, ${ }^{126}$ and this amount has been held to be as much as 20 per cent. ${ }^{127}$

\section{(b) cost of future care}

Recently in Canada the cost of future care has been the largest component of awards to plaintiffs with permanent incapacitating injuries. ${ }^{128}$ This award is given to provide money to allow for the maintenance of the plaintiff

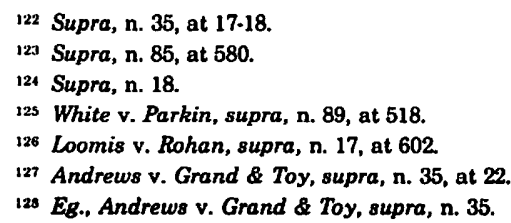


for the remainder of his or her life and is based on the particular needs of each plaintiff. The type of injury suffered affects this award, as was pointed out by Manning J.:129

The very large item for cost of maintenance is, I think, a question of fact as to how much expense there will be. In most of the cases of very serious injury this item is relatively small, apparently because either the injured person is unconscious and living in a hospital at government expense or living at home where a large part of the necessary care is from members of the family and at no calculated expense.

In some cases the cost of maintenance was not considered and a lump sum award was given to cover all aspects of the loss. ${ }^{130}$ Generally, though, some consideration is given to this head. In cases of serious brain damage the plaintiff usually requires permanent hospitalization for a life expectancy considerably reduced by the accident, and since the government pays for hospital expenses an award under this head is nominal or non-existent. ${ }^{131}$ Quadriplegics, on the other hand, since they require constant attention but do not necessarily require hospitalization, generally require large sums to allow for their future maintenance. ${ }^{132}$

The awards given are based on the actual needs of the plaintiff. Therefore, the greater the need, the greater the award. It is only recently in Canada that the courts began to hold that persons suffering from quadriplegia had the greatest needs, which include living at home rather than in an institution and the hiring of trained help. In the first case which allowed a large award, Loney v. Voll, Manning J. gave his reasons as follows: ${ }^{133}$

The net result is that in no reported case in Canada or England does there appear to have been an award actually given for maintenance that is nearly as high as the award I have decided on in this case; but in no other case has there been anything like the need demonstrated that there has been in this case. The large item is for a home and for a long life expectancy and the large expense in connection with the home is the cost of a housekeeper/attendant services.

This decision was followed in Andrews which provided a similar high award for cost of future care.

In cost of future care there are two major areas of expenditureequipment, including living accommodation, and the hiring of assistants. These items are generally listed as a monthly cost to obtain a required monthly expenditure in order to purchase an annuity to provide this amount monthly to the plaintiff. In the recent case of Thornton v. Board of School Trustees (Prince George), ${ }^{134}$ Andrews J. calculated the amount of damages for the future care of a young quadriplegic as: ${ }^{135}$

[The plaintiff] will purely and simply require this type of care for the rest of his days. After having made the necessary calculations . . a a 49 year life expectancy and a monthly cost of care of $\$ 4,305.00$, and . . \$45,000.00 for a house . . $\$ 8,500.00$ for a para-van, and $\$ 12$,000.00 for initial equipment outlay, I arrive at a total of $\$ 1,188,071.80$. . .

The equipment required varies with the type of injury the plaintiff has sustained. An unconscious plaintiff who has been hospitalized has virtually no requirements under this head. Persons who suffer from multiple injuries

\footnotetext{
129 Loney v. Voll, supra, n. 18, at 222.

130 Eg., Oman v. Public Trustee, supra, 85.

131 Eg., West v. Shephard, supra, n. 19.

132 Eg., Loney v. Voll, supra, n. 18; Andrews v. Grand \& Toy, supra, 35.

133 Supra, n. 18, at 224.5.

134 Thornton. Tanner et al. v. Board of School Trustees of School District No. 57 (Prince George), Edamura and Harrower [1975] 3 W.W.R. 622 (B.C.S.C.).

135 Id. at 648 .
} 
can require such things as ". . . electronic equipment, which can help the disabled to open doors, turn the television on, what is perhaps more important, turn it off, use the telephone and operate a typewriter by blowing down or sucking up a tube with a mouthpiece. . . ."136 Paraplegics require certain initial and recurring special expenses because of their condition. These special expenses include such items as: a wheelchair, a two-door automatic car equipped with hand controls, rubber sheeting, raised toilet seat, overhead bars and slings, repairs to and replacement of wheelchair and car, and medications. ${ }^{137}$ Special equipment required by a quadriplegic can include: a standard wheelchair, and an electric wheelchair, an Econo-van vehicle with specialized power lifts and power steering, an electrical hospital bed, Hoyer lift (with attachments), Home-aid hardware and architectural changes, electric typewriter, electric garage door opener, taperecorder, commode chair, hand-controls for van, Cairns selector control, repairs on equipment, and medications. ${ }^{138}$ The amount of special equipment increases with the severity of the injury and consequently results in greater awards.

The hiring of help is the second major portion of the award under this head. It has been put forward that ". . . the sum awarded as compensation should be sufficient to ensure that he will be properly looked after by others in any situation. . . ."139 There are two possible sources of help-one from the plaintiff's family members, and the other from persons hired to care for the plaintiff.

It is generally considered in both Canada and England that the plaintiff should not be expected to rely on assistance from family members. It would not be fair to the family of the plaintiff to "... continue to bear the whole burden of [the plaintiff's] care."140 The defendant cannot be allowed to benefit from the use of family members and consequential reduction in damages. This was aptly stated in Warren v. King by Harman L.J .:141 "Here the infant plaintiff has at present a devoted mother and family who provide the service she requires for nothing, but that happy chance should not affect the compensation." The fact that a plaintiff has no family members to rely on for assistance makes the adequacy of the award even more important to the plaintiff. ${ }^{142}$ The fact that the plaintiff cannot, or should not, be expected to rely on help from family members results in larger awards to cover the expense of hiring help. ${ }^{143}$

The amount of personal care that is required in the form of hired help varies with the incapacity of the plaintiff. A 44-year-old male paraplegic, who could move about with canes and go out with his wheelchair, required only part-time help which was ". . . available to give some help on most days." 144 Two cases involving quadriplegic plaintiffs in which lump sum awards were made recognized that constant, full-time care was required. ${ }^{145}$ In three recent cases the court calculated the cost of competent assistants. In Loney v. Voll the monthly expenses allowed included an attendant

\footnotetext{
${ }_{236}$ S. v. Distillers Co., supra, n. 16, at 123.

137 Loomis v. Rohan, supra, n. 17, at 604-5.

130 Andrews v. Grand \& Toy, supra, n. 35, at $40-42$.

139 Oliver v. Ashman, supra, n. 30, at 340.

140 Teno v. Arnold, supra, n. 33, at 64.

31 Supra, n. 86, at 529.

142 Loney v. Voll, supra, n. 18, at 199.

143 Hill v. The Queen, supra, n. 85, at 284

ist Loomis v. Rohan, supra, n. 17, at 604.

iss Bisson v. District of Powell River, supra, n. 20; Oman v. Public Trustee, supra, n. 85.
} 
housekeeper (on a 24-hour basis) at $\$ 385$, Paramedical services (pro-rated) at one visit per week at $\$ 21$, and a nursing-aid or nurse at $\$ 600$, for a total of $\$ 1$,006 monthly. In Andrews v. Grand \& Toy the estimated cost for two trained orderlies on two 10-hour shifts, allowing for holidays and sick leave, was $\$ 2$,516 per month. In Thornton v. Board of School Trustees (Prince George) the cost of orderly care was calculated as three shifts, based on 7 days a week and 8 hours a shift, at $\$ 932$ a shift, totalling $\$ 2,796$ a month.

The cost of assistance is very high because trained persons are required to assist in moving the plaintiff, to watch for and recognize signs of diseases, infections and skin breakdowns which quadriplegics are prone to, and to perform the necessary personal care which the person is unable to do for himself.

\section{(c) no overlap of heads}

In making awards under these two heads it is important to ensure that there is no overlap or duplication in the assessment. In Loney v. Voll the monthly sum calculated for the plaintiff's future care included such items as rent, utilities, food and clothing. Generally, these are considered to be normal expenditures that a person has and not consequences of the accident. In this case they were included in the monthly estimated cost because there was no award made for loss of prospective income. The award was calculated to provide only for the total maintenance of the plaintiff and no consideration was given to an award for lost future income, so it was not necessary to subtract the normal costs of living from the award for income. In Andrews v. Grand \& Toy such calculations were made. It was held that when damages are calculated under the two heads of cost for future maintenance and loss of prospective earnings, it is possible to duplicate “. . . that portion of charges representing food and board, which the injured party would have had to absorb even if he had not suffered any injury."146 It was estimated that a single male, 23 years of age, in Edmonton, in 1974, having an income of $\$ 9,960$, would spend approximately 53 per cent of his income for food, clothing, shelter, transportation and personal expenses. In order to avoid duplication of these costs the anticipated future monthly income was reduced from $\$ 830$ to $\$ 390$. The award for loss of future income was based on this lower monthly figure, while the cost of maintenance included the items listed above.

\section{Non-pecuniary Heads}

Non-pecuniary heads are those which contribute to the assessment of the award in a minor way, or put another way, are those heads which result in a smaller financial loss to the plaintiff. They are the heads which compensate for those aspects of loss which have no monetary value.

\section{(a) pain and suffering}

Pain and suffering has long been recognized as a head of damage for which compensation can be awarded. If it were not for the act of the defendant the plaintiff would not suffer from the mental and physical pain arising from the injury. Damages are generally considered to be compensation for a loss. Pain is not a loss in the true sense of the word, but the actual loss to the plaintiff is the loss of a state of freedom from pain. Both past and future pain and suffering are compensated at the same time.

If there is no pain and suffering there can be no award under this head of 
damage. Two English cases established this when the plaintiff in each was immediately rendered unconscious by the accident and thereby suffered no pain. ${ }^{147}$ It has also been remarked that: ${ }^{148}$

If there has been some serious physical injury which as the result of skilled medical attention has happily not necessitated the enduring of pain then it will follow that there will be no question of including in an award any sum as compensation for the enduring of pain.

Pain and suffering vary with the type and severity of the injury. Also, this head can include either mental or physical pain and suffering, or both. Mental suffering has been considered to be an important consideration in assessing damages for a 17-year-old woman who was rendered a quadriplegic in an automobile accident. ${ }^{149}$ Likewise, it was held that for a 41 year-old woman who suffered severe brain damage, the sum awarded for mental suffering should be "generously assessed."In this case the plaintiff understood her condition, although to what extent was difficult to ascertain, but Lord Devlin thought the "presumption should be against the defendants." The majority of the House of Lords did not decide to increase the award for mental suffering in this case despite this concern of Lord Devlin. ${ }^{150}$

Physical pain is often considered separately from mental suffering although in some cases they co-exist in the plaintiff. In a case involving a young quadriplegic, physical pain was not considered to be a significant element in the injury. ${ }^{151}$ Although quadriplegia results in a loss of the use of the body, it does not always result in freedom from pain. In a recent case involving another young quadriplegic, ${ }^{152}$ the plaintiff suffered from a numb feeling in his whole body, pain in his neck and base of his skull and spastisity of his muscles which resulted in pain. The pain was expected to remain or increase in the future. This pain resulted in a generous assessment by the trial judge under this head.

An award for pain and suffering therefore varies from no award when no pain has been experienced, for whatever reason, to a fairly high assessment when a serious combination of physical and mental pain exists.

\section{(b) loss of amenities of life}

Loss of amenities of life includes those things that reduce the plaintiff's enjoyment of life. The award is to compensate the plaintiff for the effect of his injuries on his enjoyment of life. Loss of amenities is separate from any material loss suffered. When the plaintiff is a child the award under this head has been reduced because a child "could not be expected to feel anything like the same degree of mental anguish through knowledge of her condition as would have been probable in the case of an adult." 153 Similarly, in a case where children were born with deformities caused when their pregnant mothers took the drug Thalidomide, Hinchcliff J. said: "These children were born deformed, they have never known what it is to have their limbs or to be accepted by their fellow creatures; they will never know what it is to play games with other children or be treated as normal."154 In these cases it

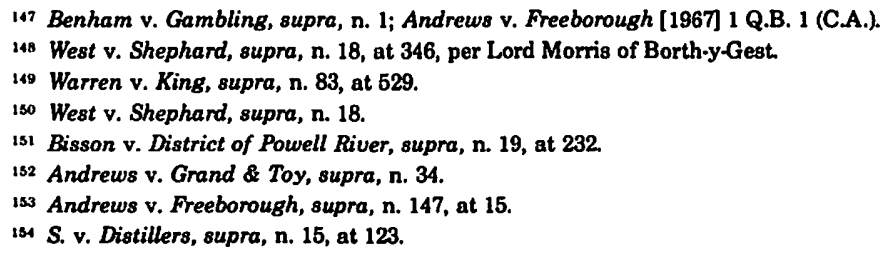


appears that the award for loss of amenities is dependent upon the plaintiff's understanding of his loss of the normal enjoyment of his former life style.

Similar rulings have been made in regard to unconscious plaintiffs. In West v. Shephard, where the plaintiff-a 41-year-old woman with severe brain damage- was rendered almost totally unconscious and would remain so until her death, Lord Devlin said:155

I think that deprivation should be measured mainly, if not wholly, by the sense of loss. . . . I consider that where there is no knowledge of the deprivation, nothing more than a conventional sum . . . should be awarded for deprivation of faculties.

In this case, Lord Devlin felt that a generous assessment should be made for loss of amenities since the plaintiff was not totally unconscious and it was very difficult to ascertain the extent to which she experienced a sense of loss.

Plaintiffs who are conscious of their loss in the enjoyment of their life are generally felt to be entitled to fair compensation. The courts recognize that a plaintiff who is severely injured, such as a quadriplegic, must suffer humiliation at not being able to perform normal functions, as well as the loss of enjoying the doing of normal activities. ${ }^{156}$ This has been expressed as: ${ }^{157}$

For him the term "amenities of life" must be a mockery. The only hope for him is that his courage and fighting spirit will make the burden of his shortened life endurable.

The Supreme Court of Canada in Jennings v. The Queen extended this head by allowing damages for a plaintiff who was and would remain totally unconscious. Cartwright J. said: "I am in full agreement with [the] view . . . that damages for loss of the amenities of life are not to be reduced by reason of the fact that the injured person is unconscious and unaware of his condition."158 From this it appears that damages for loss of amenities of life are equally available to a conscious and unconscious plaintiff in Canada. Children have recently been allowed generous compensation under this head in Canada. In Teno v. Arnold the ten-year-old plaintiff was awarded damages because she would become increasingly aware of her disability and inability to participate in certain activities requiring physical coordination. In a discussion of the reasons for, and the difficulty of awarding damages under this head, Windeyer J. in Skelton v. Collins said:159

It turns upon the plaintiff's being deprived of something that he could not have sold, his
ability to enjoy in the way that he formerly could whatever life should offer. A man whose
capacity for activity, mental or physical, is impaired, so that no longer can he get satisfac-
tion and enjoyment from things that he was accustomed to do and cannot do what he had
planned or hoped to do, has not lost a thing the value of which for him can be measured in
money by any process of calculation or estimation that I can understand. This consequence
of an injury may be called by the convenient phrase, "loss of amenities". . . . However
described, it is not a loss of something in the same sense that loss of a possession or of ear-
ning capacity is. A man who loses a limb, his eyesight, or his mind, does not lose a thing
that is his, ... but something that is a part of himself, . I am unable myself to under-
stand how monetary compensation for the deprivation of the ability to live out life with
faculties of mind and body unimpaired can be based upon an evaluation of a thing lost. It
must surely be based upon solace for a condition created not upon payment for something
taken away.

and further:

$15 s$ Supra, n. 19, at 362-63.

158 Andrews v. Grand \& Toy, supra, n. 35.

157 Bisson v. District of Powell River, supra, n. 20, at 228-29.

158 Supra, n. 100 , at 542.

139 Skelton v. Collins (1965-66) 39 A.L.J.R. 480 (H. Ct. Aust) at 495. 
$\mathrm{He}$ is, I do not doubt, entitled to compensation for what he suffers. Money may be a compensation for him if having it can give him pleasure or satisfaction. If his expected years of life have been made less, money may enable him to cram more into the time that remains. If he has been deprived of the ability to do some things that he had enjoyed doing or had hoped to do, then money may enable him to enjoy other things instead. But the money is not then a recompense for a loss of something having a money value. It is given as some consolation or solace for the distress that is the consequence of a loss on which no monetary value can be put.

\section{(c) loss of expectation of life}

This head compensates the plaintiff for the years that will be lost to him by reason that his injuries will cause a premature death. It was first allowed in Flint v. Lovell, ${ }^{160}$ in which a plaintiff was awarded compensation for the shortening of his own life. Shortly after this case was decided, the House of Lords, in Rose v. Ford, ${ }^{161}$ allowed the personal representative of a deceased plaintiff to colleet under this head.

The House of Lords considered the problems raised by claims under this head in Banham v. Gambling. ${ }^{162}$ In this case the House of Lords was asked to assess the quantum of damages that should be awarded to a child of $21 / 2$ years of age who was injured in an automobile accident and died the same day. Viscount Simon L.C., in considering this question, said that "it must be accepted that, in cases where the victim's life has been shortened by the accident ... some figure to represent the loss suffered by the deceased through the shortening of his life may be included in the damages. . . ."163 He went on to explain his reasons: ${ }^{164}$

And in any case the thing to be valued is not the prospect of length of days, but the prospect of a predominantly happy life. The age of the individual may, in some cases, be a relevant factor, . . . but . . . arithmetical calculations are to be avoided, if only for the reason that it is of no assistance to know how many years may have been lost, unless one knows how to put a value on the years.

... In assessing damages for shortening of life, therefore, such damages would not be calculated solely, or even mainly, on the basis of the length of life that is lost. . . .

The question thus resolves itself into that of fixing a reasonable figure to be paid by way of damages for the loss of a measure of prospective happiness.

The conclusion was that damages should be awarded for the loss of prospective happiness and whether for a child or adult, a "very modest figure" should be arrived at. The figure of $£ 200$ was agreed upon in this case.

The awarding of a nominal amount for loss under this head has generally been followed in Canada. ${ }^{165}$

\section{(d) conclusion}

Generally the non-pecuniary heads of pain and suffering, loss of amenities of life and loss of expectation of life are lumped together as a single amount. They are considered separately when only one is in issue, as was the case in Benham v. Gambling. In Bisson v. District of Powell River the court decided that the award for loss of life expectancy and pain and suffering would be a nominal amount.

Two recent Canadian decisions lumped these heads together but, rather than giving nominal compensation, made substantial awards to the plain-

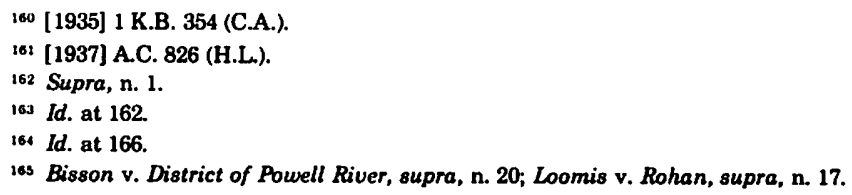


tiffs. The plaintiff in Andrews v. Grand \& Toy was awarded $\$ 150,000$ for this head, while the plaintiff in Teno v. Arnold was given $\$ 200,000$ for similar heads of damage. In both of these cases the award was based on global sums awarded in other cases where there was no breakdown into various amounts for individual heads. In both of these cases the amount for non-pecuniary heads was $15-20 \%$ of the total award which in this respect is in keeping with other awards of a smaller total value.

Non-pecuniary heads of damage are still a smaller part of a damage award, the majority of the award being given for loss of future income and cost of future care.

\section{OTHER CONSIDERATIONS}

There are also collateral considerations which affect the assessment of general damages. Though one or any of these may or may not be present in a given case, when they arise they must be taken into account. These considerations are: (i) the consideration of income tax, insurance and pensions; (ii) the use of juries; (iii) the making of an award by a lump sum or by periodic payments; and (iv) considerations on appeal. Each of these will be discussed separately.

\section{Tax, Insurance and Pensions}

(a) $\operatorname{tax}$

Whether or not income tax should be taken into consideration, and thus reduce the award, has been a much discussed question. Until British Transport Commission v. Gourley, 168 it was generally accepted in England “... that the plaintiff"s liability to tax was res inter alios acta, and that any calculation should be based on his gross income."167 The decision in Gourley changed the philosophy of the law and settled that tax was to be taken into account in the assessment of damages. Earl Jowitt gave these reasons: ${ }^{168}$

... to ignore the tax element at present day would be to act in a manner which is out of touch with reality. Nor can I regard the tax element as so remote that it should be disregarded in assessing damages. The obligation to pay tax . . . is almost universal in its application.

\section{And further: 169}

I see no reason why in this case . . . the respondent should not have his damages assessed on the basis of what he has really lost; and I consider that, in determining what he has really lost, the judge ought to have considered the tax liability of the respondent.

The result of this decision is that damage awards are calculated on the basis of what the plaintiff would have received from his income after income tax was deducted. This puts the plaintiff into the actual financial position he would have been in as far as his net income is concerned. This method is of some benefit to the defendant since he must pay a smaller amount to the plaintiff-that is, the defendant pays the plaintiff's net, not his gross lost income. This position of allowing for a reduction in the award to account for the tax has been followed in subsequent English cases. ${ }^{170}$

The position of the Canadian courts was not resolved until 1966 when the

1 se Supra, n. 29.

167 Goldsmith, supra, n. 73, at 14.

160 British Transport Commission v. Gourley, supra, n. 29, at 802

$169 \mathrm{Id}$. at 803 .

170 B.g., Cutts v. Chumley, supra, n. 2, at 749. 
Supreme Court of Canada gave its decision in The Queen v. Jennings. ${ }^{171}$ In this case the trial judge followed Gourley and deducted tax from the award for loss of future earnings. The Ontario Court of Appeal rejected this and increased the award. The Supreme Court of Canada upheld the Court of Appeal decision. Judson J. said, ". . . I think that we should say now that we reject the principle stated in Gourley.'172 and gave these reasons:173

It has been said that if the incidence of taxation on future earnings is ignored, the plaintiff is being over-compensated. With this I do not agree. A lump sum award under this head is at best no more than rough-and-ready compensation.

And further:

To assess another uncertainty - the incidence of income tax over the balance of the working life of a plaintiff-and then deduct the figure reached from an award is, in my opinion, an undue preference of the case of the defendant or his insurance company. The plaintiff has been deprived of his capacity to earn income. It is the value of that capital asset which has to be assessed. In making that determination it is proper and necessary to estimate the future income earning capacity of the plaintiff, that is, his ability to produce dollarincome if he had not been injured. This estimate must be made in relation to his net income, account being taken of expenditures necessary to earn the income. But income tax is not an element of cost in earning income. It is a disposition of a portion of the earned income required by law. Consequently, the fact that the plaintiff would have been subject to tax on future in. come, had he been able to earn it, and that he is not required to pay tax upon the award of damages for his loss of capacity to earn income does not mean that he is over-compensated if the award is not reduced by an amount equivalent to the tax. It merely reflects the fact that the state has not elected to demand payment of tax upon that kind of a receipt of money. It is not open to the defendant to complain about this consequence of tax policy and the courts should not transfer this benefit to the defendant or his insurance company.

This position has been subsequently followed in Canadian cases. ${ }^{174}$

In Jennings Judson J. did not think that an award of damages for impairment of earning capacity would be taxable under the Income Tax Act. He further stated that he knew of no decisions on this issue and that the law in this regard was uncertain. ${ }^{175}$ In 1973 the following amendment was made to the Income Tax Act ${ }^{176}$

81(1) There shall not be included in computing the income of a taxpayer for a taxation year,

(g.1) Income from property acquired as personal injury award-the income of the taxpayer for the year from any property, or any property substituted therefor, acquired by the taxpayer or by any person for the benefit of the taxpayer as an award of, or pursuant to an action for, damages in respect of physical or mental injury to the taxpayer, if the income was received

(i) by the taxpayer,

(ii) by the taxpayer's guardian, curator tutor, committee or other legal representative, or

(iii) by an officer of a court for the benefit of the taxpayer,

before the taxpayer attained the age of 21 years; $176 a$

เ71 Supra, n. 108.

172 Id. at 547.

173 Id. at 545-46.

174 E.8., Lillico v. Glimps, supra, n. 92; Loney v. Voll, supra, n. 18; Ofstedahl v. Cam.Set Mechanical Contractors Led. [1974] 1 W.W.R. 329 (Alta. C.A.).

173 Jennings v. The Queen, supra, n. 108, at 544.

176 Income Tax Act, Statutes of Canada 1973.74, c. 14, s. 23(2) amending Statutes of Canada 1970-71-72, c. 63, 8. 81(1), assented to April 18, 1973.

${ }^{1789}$ This section was further amended by S.C. 1974-75, c. 26, Royal Assent March 13, 1975 as follow8:

44.(2) All that portion of paragraph $81(1)(g .1)$ of the said Act preceding subparagraph (i) thereof is repealed and the following substituted therefor.

" $(\mathrm{g} .1)$ the income of the taxpayer for the year from any property, or any property substituted therefor, or the taxable capital gain of the taxpayer for the year from the disposition of any such property, acquired by the taxpayer or by any person for the benefit of the taxpayer as an award of, or pursuant to an action for, damages in respect of physical or mental injury to the taxpayer, if the income or taxable capital gain was received".

This change does not affect the content of this paper nor the treatment of this section by the courts on this study. 
The important words of this section appear to be:

There shall not be included in computing the income of a taxpayer for a taxation year, the income ... from any property . . . acquired . . . as an award of. . . damages in respect of physical or mental injury . . . before the taxpayer attained the age of 21 years.

A taxpayer under the Act "includes any person whether or not liable to pay tax."177

This section, although being law for over a year, has been considered only in the recent case of Teno v. Arnold. ${ }^{178}$ In this case damages were awarded to an infant plaintiff with severe brain damage, who was four years old at the time of her accident, and ten years old at the trial. Keith J., in considering this amendment to the Income Tax Act, said:179

... income arising from an award of damages is not taxable until the taxpayer attains the age of 21 years. This feature, if maintained in our tax law, and I can make no assumption one way or another, would mean that investment income available for this child's support will not be reduced by taxation for about eleven more years [until age twenty-one].

Keith J. discussed the Jennings case and noted that it did not apply to the facts of the present case. In Jennings the damage award was for loss of future income. The consideration made in that instance was whether or not income tax should be calculated in the lost earnings of the plaintiff. It had been decided earlier in Gourley that the plaintiff should receive only his net income, or that which he would have received after tax had been removed. The Jennings case reversed this and held that the defendant should not benefit in this manner and that tax should not be taken into consideration, giving the plaintiff his gross earnings. Keith J. noted that the Teno case was for cost of future maintenance and not for loss of future income. He therefore concluded that Jennings had no bearing on the present decision.

Following this discussion he went on to state: 180

I therefore propose to take the possible incidence of taxation into account in my assessment. Fiscal policy is not static-for instance it is only recently that capital gains, and then only some, have attracted tax. Having regard to the sum that the present assessment must involve, I would guess ... there being no evidence except present tax law, that as much as one third requires to be added to that portion of my assessment related to the cost of future maintenance to protect this plaintiff against taxation.

It appears from this that, for a plaintiff over the age of 21 years, all income arising from the award regardless of whether the award was under the heading of cost of future care, for loss of future income or as a lump sum award is taxable. Persons under 21 years are exempt from this income tax by virtue of the following provisions of the Income Tax Act:

81(1)(g.2) Income from income exempt under para. (g.1). - any income of the taxpayer for the year (other than any such income received after he attained the age of 21 years) from any income that is, by virtue of paragraph (g.1) or this paragraph, not required to be included in computing the taxpayer's income for any taxation year;

81(1)(g.3) Interest paid on property acquired as award and held for benefit of taxpayer under 21 years.- any amount paid to the taxpayer in the year by a person described in subparagraph (g.1)(ii) or (iii) as, on account or in lieu of payment of, or in satisfaction of, interest on

(i) any property, or any property substituted therefor, acquired by or for the benefit of the taxpayer as described in paragraph (g.1), or

(ii) any income of the taxpayer from any property referred to in subparagraph (i),

in respect of a period during which

177 Income Tax Act, k.S.C. 1970 c.I-5, 8. 248(1).

178 Supra, n. 33.

$179 \mathrm{Id}$. at 71.

100 Id. at 73 . 
(iii) the property or the income, as the case may be, was held or was received and held, as the case may be, by that person or, if that person was an officer of a court, under his jurisdiction, and

(iv) the taxpayer was under the age of 21 years;

These sections have been explained in the Master Tax Guide as follows: ${ }^{180}$

\begin{abstract}
Amounts not included in income-Personal injury awards. Where an infant has suffered mental or physical injury and has received an award or a settlement in respect of an action for damages, the property awarded or received is usually held in trust for the infant by his legal representative or by an officer of a court until the infant attains the age of majority. The income, including interest, arising from the investment of such property is excluded from tax while the infant is under the age of 21 . The exclusion applies not only to income arising from the property directly but also from property which has been substituted on one or more occasions for the property received in the award or settlement. Furthermore the excluded income itself may generate additional income which is also excluded from taxation.

The foregoing provisions will not apply in other situations, such as where the infant receives an award under fatal accidents legislation for the death of a parent.

Notwithstanding the fact that in many provinces the age of majority is 18 , the infant taxpayer will continue to benefit from the foregoing income exclusions until he attains the age of 21 .
\end{abstract}

The court in Teno by adding one-third unto the total award attempted to provide the plaintiff with the money to pay the tax on the award, once it became taxable. In doing this, the court's apparent intention was to ensure that the award, which was to provide for the plaintiff's future maintenance, would not be reduced by taxation. Because the tax is on the income from the award and not the capital of the award the increase allowed in Teno may be unnecessary protection for the following reasons:

(i) The basic award was calculated to provide for the plaintiff for the remainder of her life. This sum was not taxable in any manner until she reached 21 years, and thereafter only the income from this capital sum would be taxable. Income from the award was not calculated to be a part of the sum required to maintain the plaintiff and this sum might be regarded as money incidental to the award. Because of this, any income from the award, not being required to maintain the plaintiff, could be reduced by paying the required tax out of this income and the plaintiff would not suffer unduly, since she would be maintained by the capital amount.

(ii) The provisions of the Act which allow income to be non-taxable until age 21 allow the plaintiff the opportunity of accumulating a sum of money which may not be taxable at any time, since it is income earned after age 21 which is taxable. The plaintiff receives an extra benefit in this regard.

(iii) After the age of 21 years the award may possibly be subject to double taxation on some of the income since the Act provides that income from capital gains and annuities is taxable. This, if it is the case, would not put undue hardship on the plaintiff since the capital amount remains untaxed. (iv) Causing the defendant to pay one-third more in damages to account for tax may cause unwarranted hardship on the defendant. In this case the plaintiff would possibly be able to pay the tax from the income. If the award was for lost future earnings, as in Jennings, and not for cost of future care, and if the court in assessing damages followed both Jennings and Teno, the award would have a double tax calculation included. It would be an assessment of the gross lost earnings of the plaintiff, i.e. including the income tax, and also including an additional increase of the award, up to one-third, to "protect" the plaintiff from taxation under the Income Tax Act. 
How these problems are resolved is now up to the courts who must decide if the provisions of the Act should be taken into account in making an award, or whether awards should be made as they were before the amendment, leaving taxation problems to the Department of National Revenue.

\section{(b) insurance and pensions}

Money received by the plaintiff from other sources such as his own insurance policies, pensions or unemployment benefits must not be taken into account when assessing damages, since the defendant cannot take advantage of the plaintiff's good fortune at having such help. ${ }^{181}$ Sick benefits received from an employer, ${ }^{182}$ disability benefits and payments under the Canada Pension Plan ${ }^{183}$ do not need to be taken into account.

\section{Considerations on Appeal}

Because of the questions of liability involved, the serious nature of the injuries suffered, and the large awards obtained, many of the cases involving permanent incapacitating injuries are appealed. The principles by which a court of appeal assesses the quantum are settled law; it is the application of the principles which gives the courts difficulty.

The trial judge has the duty to assess damages which he is satisfied are right and proper in light of the evidence before him, and not to project himself into the mind of the appellate court and assess damages as he thinks it would. ${ }^{184}$ The court of appeal, when deciding if the amount assessed by the trial judge is the right amount, has many factors to consider. The fact that an award is high does not mean that it is excessive and to be consequently reduced. ${ }^{185}$ Lord Morris of Borth-y-Gest held that an award should be overruled only if the appeal court is satisfied that it is excessive. He said in West v. Shephard:186

. . . the figure of $£ 17,500$ may seem high but I am not persuaded that the learned judge who fixed it and those who approved of it are shown to have been in error. I ought not to differ from them unless I am persuaded that they have awarded or allowed a figure which is shown to be unreasonable and excessive and out of proportion having regard to the injuries sustained. I ought not to overrule their discretion and their act of judgment unless I am so satisfied.

An award may be considered excessive if it is out of line with awards for similar injuries. This was the case in Sabel v. Williamson, in which Monnin J.A. of the Manitoba Court of Appeal said: ${ }^{187}$

In Canada there is therefore a range of from $\$ 32,000$ to $\$ 180,000$ and in England from $£ 11$, 000 to $\$ 35,000$. Converted to Canadian money ... of $\$ 33,000$ to $\$ 105,000$.

\section{And further.}

In my view the learned trial Judge's award of $\$ 123,000$ is inordinately high and out of line with other awards in comparable Canadian and United Kingdom cases. Plaintiff was seriously injured but is able with difficulty to shave and eat, and has suffered no brain impairment. He is not in as serious a condition as many of the plaintiffs in the cases above referred to.

An award ought not to be reduced ". . . because of the unlikelihood that

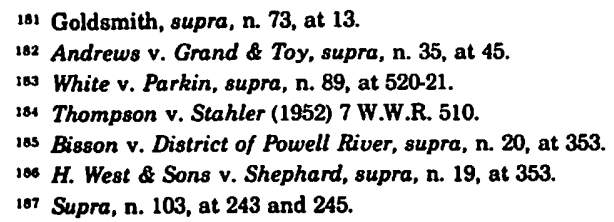


the victim will be able to use or dispose of it all." 188 When a trial judge fails to include an important element, such as the need for future maintenance, in his reasons for assessment a court of appeal can increase the award to include this. ${ }^{189}$

When assessing the quantum of damages set by a jury the court must consider the matter of the assessment in a somewhat different light. A jury is composed of people who are usually unfamiliar with the legal system and with computing damages; therefore, the judge must direct the jury so that they will be able to arrive at an award. If the judge misdirects the jury by not warning them to avoid duplication in the award, an appeal court can overrule their decision and re-evaluate the damages. 190 To reject a jury decision the amount must be wholly out of proportion to the case. This has been set out by the Supreme Court of Canada: ${ }^{191}$

The principle has been laid down in many judgments of this Court to this effect, that the verdict of a jury will not be set aside as against the weight of evidence unlessitis so plainly unreasonable and unjust as to satisfy the Court that no jury reviewing the evidence as a whole and acting judicially could have reached it.

\section{The Use of Juries}

\section{(a) purpose}

Juries are rarely used in civil trials in Alberta today for reasons outlined below. This discussion therefore has little practical value except to show the principles upon which cases have been tried, and are being tried in other jurisdictions where juries are used. When there is no jury the judge is the trier of fact in its place.

Generally questions of fact are determined by the jury while questions of law are determined by the judge. The jury must listen to the evidence presented by both sides and then decide which facts alleged have been established. Itmust then, using these facts, decide for the plaintiff or the defendant. If it finds the defendant liable for negligence, it must also determine whether or not the plaintiff was contributorily negligent. If negligence is found, the jury must assess the quantum of damages which is to be awarded to the plaintiff. The jury, therefore, has three major functions: (i) to find the facts of the case; (ii) to determine the degree of liability of the parties; and (iii) to assess damages. These must be dealt with as separate considerations and the jury must assess damages without regard to the degree of fault or negligence of the parties involved. ${ }^{192}$

\section{(b) judge's control of the jury}

A jury is composed of six or twelve persons who are untrained in the law. They must, without the benefit of any legal knowledge, draw inferences and form an opinion as to what the facts of the case were, based on the evidence before them, and they must make a decision based on these facts. In order that this be accomplished it is the right and duty of the trial judge to instruct the jury in a number of ways.

The judge must decide if there is any evidence to go to the jury. This decision is based on the law of evidence, and being a decision of law it is within the scope of duties of the judge. If there is no evidence that is admissible the

\footnotetext{
188 $H$. West \& Sons v. Shephard, supra, n. 19, at 363, per Lord Devlin.

189 Hill v. The Queen, supra, n. 85, at 284.

190 Bisson v. District of Powell River, supra, n. 20.

191 McCannell v. McLean [1937] S.C.R. 341, at 343, per Sir Lyman Duff C.J.

102 Bedford and Stanton v. Crapper [1949] O.W.N. 266; [1949] 3 D.L.R. 153 (C.A.).
} 
case is withdrawn from the jury, otherwise only the admissible evidence is presented to the jury. It is only from this evidence that the jury can makeits decision. The judge must sum up the evidence at the end of the trial, and present the evidence of both sides of the case for the jury's consideration.

The judge may participate in the examination of witnesses if their testimony leaves uncertainties, if terminology is undefined, if gaps are left, or if the answers do not go to the root of the issue. This is not done often but it is a manner in which the judge can influence a jury.

The judge also must explain to the jury the doctrine of presumptions, and explain the area of law with which the trial is concerned. The explanation must be clear so that the jury will be able to apply correctly the facts to the law.

In these ways, and others which are outside the scope of this paper, the judge has some control over the decision of the jury.

\title{
(c) disadvantages of the jury system
}

It has been held that "twelve heads should be better than one"193 when assessing damages, but some courts have felt that juries are less than fair to injured parties. Mr. Justice Keith, in Teno v. Arnold, a case which was originally set down to be tried by jury but which at counsel's request was tried by judge alone, said in an obiter comment: ${ }^{194}$

\begin{abstract}
... setting a dollar figure by way of compensation for personal injuries must be one of the most inexact sciences known to man rather in the category of economic or weather forecasting. Juries are constantly being required to do just this and it is hoped that in arriving at a figure they fairly represent a view acceptable to the jury's contemporary society. But even this hope fails from time to time when, assuming proper instructions, juries clearly do not treat litigants fairly.
\end{abstract}

The belief that juries are unfair to litigants was developed in Ward v. James, ${ }^{195}$ when Lord Denning M.R. outlined the reasons for the decline of the civil jury. In his reasons for judgment, Lord Denning said:196

It begins to look as if a jury is an unsuitable tribunal to assess damages for grave injuries, at any rate in those cases where a man is greatly reduced in his activities. He is deprived of much that makes life worthwhile. No money can compensate for the loss. Yet compensation has to be given in money. The problem is insoluble. To meet it, the judges have evolved a conventional measure. They go by their experience in comparable cases. But the juries have nothing to go by.

Judges have access to cases which have awarded damages for similar injuries and they are aware of the usual amounts or range of awards that are given. Juries, on the other hand, since they do not have legal training and do not have access to or knowledge of previous similar cases, are unaware of the usual dollar value placed on various types of physical injury. In addition to this, neither of the counsel, nor the judge is allowed to inform the jury of such former awards.

This lack of knowledge on the part of the jury has contributed to the belief that a judge sitting alone can better calculate an award. Mr. Justice Monnin expressed this view in Sabel $\mathrm{v}$. Williamson, when he said:197 "It is this . . consideration which makes a Judge, sitting without a jury, more moderate in assessing damages than 12 members of a jury gathered

\footnotetext{
tw Bocock v. Enfield Rolling Mills Ltd. [1954] 1 W.L.R. 1303, at 1305, per Singleton LJ., cited in Scott v. Musial [1959] 2 Q.B. 429, at 436 .

194 Supra, n. 33, at 66.

195 [1966] 1 Q.B. 273 (C.A.).

108 Id. at 296.

107 Supra, n. 103, at 237.
} 
together for probably the first and only time in their lives to establish an award-and this without guidance or reference to prior awards." Lord Denning, in Ward v. James, stated that this use of juries creates uncertainty in the law. He said:198

\begin{abstract}
. . . recent cases show the desirability of three things: First, accessibility: In cases of grave injury, where the body is wrecked or the brain destroyed, it is very difficult to assess a fair compensation in money, so difficult that the award must basically be a conventional figure, derived from experience or from awards in comparable cases. Secondly, uniformity: There should be some measure of uniformity in awards so that similar decisions are given in similar cases; otherwise there will be great dissatisfaction in the community, and much criticism of the administration of justice. Thirdly, predictability: Parties should be able to predict with some measure of accuracy the sum which is likely to be awarded in a particular case, for by this means cases can be settled peaceably and not brought to court, a thing very much to the public good. None of these three is achieved when the damages are left at large to the jury.
\end{abstract}

This apparent uncertainty and unfairness which results from jury made awards has been disputed by Linden and Sommers. ${ }^{199}$ In their study they state that civil jury trials are criticized because ". . . they are easily influenced by emotional appeals, they tend to find for the plaintiff; because they are plaintiff-minded they tend to award damages that are too high; because they are laymen, inexperienced in the law, the pace of litigation is slowed down." 200 These criticisms, they submit, are not supported by empirical data. A study of 121 automobile cases from the SupremeCourt of Ontario was conducted. The results of this data showed:201

... the inescapable conclusion to be drawn is that they [the data] do not support most of the criticisms of the jury system. Rather than finding in favour of the plaintiff all of the time, the jury nolds completely in his favour less often than does the judge alone. . . . Nor does the jury consistently assess higher damages; indeed, juries bring in more small assessments and the same number of large ones. ... On the question of delay in getting to trial, jury trials are no slower than non-jury trials in this respect; . . . One complaint was proved correct; a longer time period is necessary to try a jury case, an average of one-half of a day.

Despite these findings, civil jury trials appear to be on the decline and in some jurisdictions are an almost rare occurrence.

\title{
(d) appealing a jury decision
}

The parties to a civil action must have chosen that it be tried by a jury, and it is partly because of this fact that appeal courts are reluctant to interfere with the findings of a jury. There is a difference between the treatment of an appeal made from the decision of a judge and one made by a jury. Lord Morris, in Scott v. Musial, expressed this difference in the following way: 202

Where there is an appeal from the decision of a judge sitting alone, the appeal is by way of rehearing. The rehearing applies to the issue of damages as well as to other issues. . . But, if there has been an assessment of damages by a jury, the function of the Court of Appeal on a complaint that damages are too high or too low is different.. . . On appeal, always assuming that the trial has been properly conducted and that the jury have been properly directed, it is not for the members of the Court of Appeal to seek to substitute their assessment and their judgment for that of the jury; the function of the Court of Appeal is then directed to considering whether or not the figure stated by the jury is out of all proportion to the circumstances of the case.

198 Supra, n. 4, at $299-300$.

199 Linden and Sommers, The Civil Jury in the Courts of Ontario: A Postscript to the Osgoode Hall Study [1968]6 Os. goode Hall LJ. 252

200 Id. at 252.

201 Id. at 258.

202 [1959] 2 Q.B. 429, at 437. 
This is a difficult task since the jury gives no reasons for its decision, do not state the facts upon which their decision is based, and the jury is ignorant of relevant information on personal injury assessments from similar cases. ${ }^{203}$

A court of appeal cannot without reason change an award made by a jury. The jury award can be set aside if there has been a misdirection by the judge when summing up the evidence or in outlining the law to be considered. This will result in the ordering of a new trial which will rehear the evidence and arrive at its own conclusion as to liability and damages. ${ }^{204} \mathrm{An}$ award made by a jury may also be set aside if it is excessive and". . . wholly 'out of proportion' and so unreasonable that no twelve sensible men acting judicially with the facts as above could think that the verdict was right."205 If the excessiveness of the award is reasonably capable of ascertainment on a mathematical basis, the court of appeal may reduce the award and order a new amount in its own judgment, rather than return the question to a jury. 206

\section{(e) conclusion}

Trial by civil juries has declined in favour of trial by judge alone. The reasons for this include the fact that juries know nothing of the law of damages, are influenced by the judge, and have tended to be irregular in their assessments. It is felt that some litigants choose a jury trial when they have a weak case and a desire to appeal to the sympathy of the jury.

\section{CONCLUSION}

Damage awards have traditionally been calculated to provide an injured person with fair but not perfect compensation for his loss. This has occurred up to the present time ${ }^{207}$ with the exception of three decisions which have deviated from the usual assessments. These divergent awards have attempted to provide a more exact form of compensation by calculating the cost of every possible item required for complete home care.

Now that such large personal injury awards have been made it appears to be the time to re-define the emphasis and purpose of such awards and to determine their future. It has been believed for a long time that damages should compensate a person for his injury, but that it is impossible to provide perfect compensation. A smaller award admittedly does not truly compensate a plaintiff for the loss of his body or mind, but in many respects no amount of money can do that. Another factor that bears consideration is the effect of a large sum of money on the life of the plaintiff, a person who has just undergone a complete change in his life and ability to control it. It has never been the function of our courts to dictate the spending of damage awards, but it may be the time for rethinking on this issue. Mr.

\footnotetext{
203 Ward v. James, supra, n. 195, at 301.

204 Bisson v. District of Powell River, supra, n. 20, at 243.

205 Id. at 243.

200 Id.

207 Jackson v. Millar (1975) 4 N.R. 17 (S.C.C.) (A 16 year old boy who became a paraplegic after a motor vehicle accident was awarded $\$ 95,000$ general damages. This amount was based on the cost of an annuity to last his life expectancy of 32.5 years, and included \$2,805 per year for hospitalization, \$1,500 per year for additional expenses due to his injury and \$2,500 per year for diminution of eaming ability); Hamel et al v. Prather, Laudon and Alberta Motor Association (Third Party) [1975] 2 W.W.R. 681 (Alta. S.C.) (\$200,000 general damages awarded to a 11 year old girl for head injuries causing serious brain damage which resulted in an inability to communicate, physical disabilities, shortened life expectancy and constant care); Bogusinski et al v. Rashidagich [1974] 5 W.W.R 53 (B.C.S.C.) (A 13 year old boy who suffered brain damage resulting in loss of ability to work was awarded \$200,000 general damages); White et al v. Parkin et al; Hartford Fire Insurance Co., Third Party (1974) 46 D.L.R. (3d) 411 (B.C.S.C.) (Man awarded $\$ 250,000$ general damages for loss of mental capacity); MacLean v. Wamboldt (1974) 7 N.S.R. (2d) 10 (N.S.S.C.) (Father who was rendered a paraplegic and had life expectancy reduced to 15 years was awarded $\$ 70,000$ general damages).
} 
Justice Manning, in Loney v. Voll, suggested that courts have inherent jurisdiction over damage awards to the extent of directing they be paid to a trustee so that no person can take advantage of a severely injured person and persuade him to spend the money in such a way that it will be lost and not available for the purpose for which it was awarded. As well as controlling who spends the award it may be time to consider what the award is spent on. These large amounts were determined by, sometimes exact, calculations of the needs for future care of the plaintiff and were designed to provide for the equipment and personnel to care for him on a personal basis during his remaining lifetime. Should it be a consideration that a plaintiff may not purchase such equipment for himself, but instead uses that which is available at public hospitals? Another factor which may deserve some consideration is the effect of a million dollar award on the defendant who may only have minimum liability insurance.

The recent drastic deviations in personal injury awards may cause these, and other, factors to be of some or more concern in the calculations which produce the quantum. The fate or future of million dollar damage awards is now in the hands of our courts of appeal. It is their task to decide if such awards are excessive and out of step with our law, or if these particular awards will be the first of a new dimension to Canadian tort law. 